\title{
Effectiveness of small road tunnels and fences in reducing amphibian roadkill and barrier effects at retrofitted roads in Sweden
}

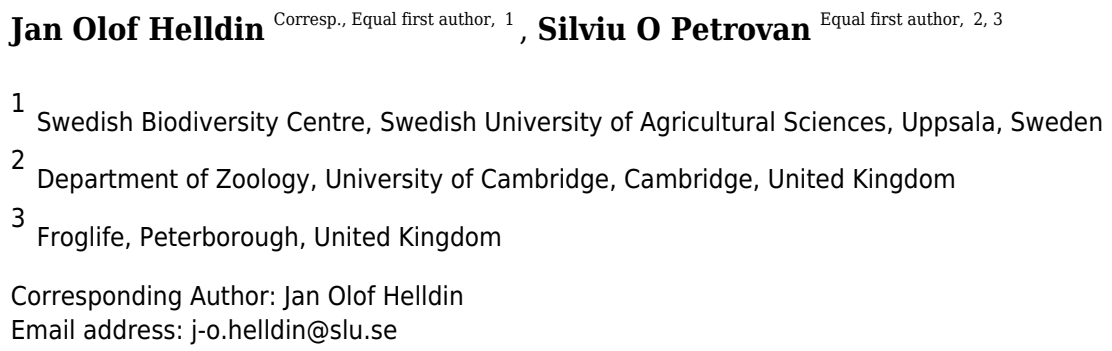

Schemes to reduce road impacts on amphibians have been implemented for decades in Europe, yet, several aspects on the effectiveness of such schemes remain poorly understood. Particularly in northern Europe, including Sweden, there is a lack of available information on road mitigation for amphibians, which is hampering implementation progress and cost-effectiveness analyses of mitigation options. Here we present data derived from systematic counts of amphibians during spring migration at three previous hot-spots for amphibian roadkill in Sweden, where amphibian tunnels with guiding fences have been installed. We used the data in combination with a risk model to estimate the number of roadkills and successful crossings before versus after mitigation and mitigated versus adjacent non-mitigated road sections. In mitigated road sections, the estimated number of amphibians killed or at risk of being killed by car traffic decreased by $91-100 \%$ and the estimated number successfully crossing the road increased by $25-340 \%$. Data however suggested fence-end effects that may moderate the reduction in roadkill. We discuss possible explanations for the observed differences between sites and construction types, and implications for amphibian conservation. We show how effectiveness estimates can be used for prioritizing amphibian passages along the existing road network. Finally, we emphasise the importance of careful monitoring of amphibian roadkill and successful crossings before and after amphibian passages are constructed. 
1 Manuscript title:

2 Effectiveness of small road tunnels and fences in reducing amphibian

3 roadkill and barrier effects at retrofitted roads in Sweden

4

5

6 Authors:

7 Jan Olof Helldin ${ }^{*}$ and Silviu O. Petrovan ${ }^{2,3}$

8

9 1) Swedish Biodiversity Centre, Swedish University of Agricultural Sciences, Uppsala, Sweden

10 2) Department of Zoology, University of Cambridge, Cambridge, $U K$

11 3) Froglife, Peterborough, UK

12 * Corresponding author j-o.helldin@slu.se

13

14

15 


\section{Abstract}

Schemes to reduce road impacts on amphibians have been implemented for decades in Europe, yet, several aspects on the effectiveness of such schemes remain poorly understood. Particularly in northern Europe, including Sweden, there is a lack of available information on road mitigation for amphibians, which is hampering implementation progress and cost-effectiveness analyses of mitigation options. Here we present data derived from systematic counts of amphibians during spring migration at three previous hot-spots for amphibian roadkill in Sweden, where amphibian tunnels with guiding fences have been installed. We used the data in combination with a risk model to estimate the number of roadkills and successful crossings before versus after mitigation and mitigated versus adjacent non-mitigated road sections. In mitigated road sections, the estimated number of amphibians killed or at risk of being killed by car traffic decreased by 91$100 \%$ and the estimated number successfully crossing the road increased by $25-340 \%$. Data however suggested fence-end effects that may moderate the reduction in roadkill. We discuss possible explanations for the observed differences between sites and construction types, and implications for amphibian conservation. We show how effectiveness estimates can be used for prioritizing amphibian passages along the existing road network. Finally, we emphasise the importance of careful monitoring of amphibian roadkill and successful crossings before and after amphibian passages are constructed.

\section{Introduction}

Amphibian populations may be severely impacted by road mortality and barrier effects of roads and traffic (Hels \& Buchwald, 2001; Gibbs \& Shiver, 2005; Jaeger \& Fahrig, 2004; Nyström et al., 2007; Beebee 2013). Mass mortalities of amphibians often occur where roads cut across annual migration routes between hibernation and breeding habitats. Roadkill, habitat loss and the generally harsh environment for amphibians along roads can also lead to avoidance and barrier effects (de Maynadier \& Hunter Jr, 2000; Fahrig \& Rytwinski, 2009), preventing them from reaching crucial habitats or resources. Aiming to reduce such negative effects, road mitigation measures have been developed and implemented for over 40 years in Europe (Langton 2015). However, monitoring of mitigation measures is often lacking or insufficient (e.g., focusing solely on usage) and previous studies have shown varying results (e.g., Brehm, 1989; Meinig, 1989; 
Zuiderwijk, 1989; Puky \& Vogel, 2003; Mechura et al., 2012; Faggyas \& Puky, 2012; Ottburg \& van der Grift, 2019; Matos et al., 2019). Consequently, numerous aspects on the actual effectiveness of road mitigation schemes for amphibians remain poorly understood, hampering cost-effective planning efforts and opportunities for improvements.

Well-functioning mitigating schemes for amphibians are strongly needed as populations of amphibians continue to decline in Europe, including some of the main target species for road mitigation, the common toad (Bufo bufo), the common frog (Rana temporaria) and the great crested newt (Triturus cristatus) (Bonardi et al., 2011; Beebee, 2013; Petrovan \& Schmidt, 2016; Kyek, Kaufmann \& Lindner, 2017). In northern Europe, including Sweden, there is however a widespread lack of available information on the effectiveness of road mitigation for amphibians. This is particularly concerning due to the well-developed road network and the potentially complex effects of the harsher climate on microclimatic conditions inside wildlife underpasses or other unforeseen aspects. The absence of structured information and evidence of effectiveness is hampering implementation progress and much needed cost-effectiveness analyses of mitigation options.

To minimise the road impacts on amphibians, road managers in and near Stockholm (the Swedish Transport Administration and Stockholm Municipality) constructed passages for amphibians at three sites where large concentrations of amphibians were killed on roads, particularly during spring migration, and thus were considered road sections in critical need of ecological mitigation. The passages were in the form of permanent tunnels with double-sided guiding fences intended to lead the amphibians safely under the road in both directions. The constructions largely followed the European (Iuell et al., 2003) and Swedish (Eriksson, Sjölund \& Andrén, 2000; Banverket, 2005) guidelines for design and dimensions, however with tunnels narrower than the recommended minimum diameter 0,6-1 $\mathrm{m}$ and with a distance between neighboring tunnels in some cases longer than the recommended maximum of 30-60 m.

Before and after the construction of these passages, the number and location of amphibians on the road as well as along the fences and in the tunnels were recorded, as the basis for planning of the mitigation constructions and monitoring of their effectiveness. Here we summarise the results of these counts, and discuss the implications in terms of reduced roadkill and barrier effect, differences between constructions, and improved amphibian conservation. We propose a baseline 
76 for prioritizing amphibian passages along the existing road network, and suggest some directions

77 for further studies that would support the planning of amphibian mitigation schemes.

78

79

80

81 82

\section{Material and methods}

\subsection{Study sites and available field data}

The three monitored sites are similar in several respects. The roads are all of intermediate size (7-8 $\mathrm{m}$ wide, ca 3,000-9,000 vehicles per average day; Table 1), and mainly used for local and commuting traffic in Stockholm metropolitan area (Fig. 1). The landscape is a small-scale valley terrain at 10-30 m elevation, with a mix of forest, farmland and housing/garden areas. The mitigated road sections all have an important amphibian breeding wetland of around 5-10 ha nearby (Fig. 2) and main overwintering habitat, typically woodland, on the opposite side of the road). Before mitigation, the road sections were well known hot-spots for amphibian roadkill during spring migration. The amphibian species diversity in the region is limited, with only five species occurring; common toad, common frog, moor frog (Rana arvalis), smooth newt (Lissotriton vulgaris) and great crested newt.

The mitigation systems are roughly similar in terms of dimensions of tunnels and fences and length of road section mitigated, while there are some differences in exact dimensions and material of the constructions (Table 1, Fig. 3). At all sites, tunnels were impacted by running or standing water to a varying degree during the studies (Table 1).

Live and dead amphibians were counted along the road prior to construction of the passage ("before"), aiming to identify the most critical road sections for mitigation and to locate major migration routes where tunnels should be placed. Amphibians were also counted post-mitigation ("after"), along the road, along fences and in tunnels, to assess the anticipated reduction in roadkill and evaluate the use of the tunnels. While the field efforts varied between sites and periods (Table 2 and site descriptions below), all data collection was conducted during peak spring migration, with methods that could be considered comparable in terms of number of amphibians found per time and road interval. 
103

104

105

106

107

108

109

110

111

112

113

114

115

116

117

118

119

120

121

122

123

124

125

126

127

128

129

130

131

132

133

Site 1 Skårby

The pond and wetland at Skårby has one of Sweden's largest breeding populations of great crested newt (>300 individuals) and also a large breeding population of smooth newt $(>2000$ individuals; Peterson \& Collinder 2006). The amphibian mitigation system was constructed in phases; $300 \mathrm{~m}$ permanent fence with three tunnels was constructed in 2005 and two additional tunnels were constructed in 2008. Amphibians on the road were counted in one night in the year before mitigation (2004), and in four nights with the mitigation in place (2008). The road section searched was ca $520 \mathrm{~m}$, extending in both directions $\geq 150 \mathrm{~m}$ outside of the section to be mitigated. Live animals and fresh carcasses (from the current night) were counted. Trapping in tunnels was conducted during five nights in total (two in 2010 and three in 2013). Bow net traps were mounted on the tunnel exits (i.e., the opening on the wetland side) to count amphibians passing through the tunnels toward the wetland. One of the tunnels (no. 2) could not be monitored because the exit was completely under water; however this tunnel was in place already before the mitigation system was constructed, functioning as a drainage pipe, and it was therefore was not further considered in the analyses. All study nights were selected to represent important migration nights (suitable weather conditions and timing). Position, species, status (e.g., dead/alive) and time was recorded for all amphibian observations, both on the road and in the tunnels. Due to the dominance of newts at this site (ca 98\% of amphibians observed) we excluded data on other species, and we pooled the data on the two newt species in the analyses. Most of the newts found when searching the road were dead (ca 72\%).

\section{Site 2 Kyrksjölöten}

The lake Kyrksjön and adjacent wetlands in the nature reserve Kyrksjölöten has a large breeding populations of common toad (the exact number has however not been assessed). The numbers of other amphibians are small. The amphibian mitigation system was constructed at the major road (Spångavägen) going past the area, in connection to an upgrade of the road in autumn 2014. Amphibians were counted during 17 evenings in 2012, before mitigation was installed, at a onesided temporary fence and pitfall traps along the section to be permanently mitigated, and by searching the road and verges. Only on 7 of the 17 nights a relatively large number of amphibians were found or trapped, and accordingly could be labelled significant migration night. Amphibians were counted during three evenings in 2015, with the mitigation in place, along the permanent fences and on the road and verges. Evenings for fieldwork were selected to represent 
134 important migration evenings (suitable weather conditions and timing). Dead amphibians had

135 accumulated between evenings, thus representing a total period of ca 8 days. The total road

136 section searched was ca $1000 \mathrm{~m}$ (same section before and after), therefore extending in both

137 directions $>200 \mathrm{~m}$ outside of the fenced section. Customised infrared timelapse cameras $(15 \mathrm{~s}$

138 interval) assembled by Froglife (Jarvis, Hartup \& Petrovan, 2019) were mounted on the ceiling

139 inside both tunnel entrances during 32 days in 2015. Only on 14 of the 32 days a significant

140 number of amphibians were recorded, and accordingly could be labelled significant migration

141 night. Position, species, status (e.g., dead/alive) and time were recorded for all amphibian

142 observations, both on the road, along fences and in the tunnels. For animals on tunnel photos,

143 movement direction (in or out) was noted and the minimum net number through the tunnels was

144 calculated. Due to the dominance of common toads at this site (ca 99\% of amphibians observed)

145 we excluded data on other species. Most of the toads found when searching the road were dead

146 (ca 82\%), while all toads found or captured along the temporary fence were alive.

\section{Site 3 Skeppdalsström}

148 The wetland Skeppdalsträsk serves as breeding area for all five amphibian species. Breeding 149 populations during studies were estimated to 600 common toads, 150 common frogs and 60

150 moor frogs (Andersson \& Lundberg, 2015); smooth newt was not included in the assessment but

151 is probably at similar abundance with common toads, while great crested newt was not

152 discovered until 2017 (Anne Crussell, pers. comm.). Volunteers have been active on the site

153 since 2013, moving amphibians across the road during spring migration. The amphibian

154 mitigation system was constructed in summer 2015. Amphibians were counted during seven

155 evenings in 2015, before mitigation was installed, by searching the road, including the verge on

156 the northern side, and during four evenings in 2016, with the mitigation in place, along the

157 permanent fences and on the road and northern verge. Evenings for fieldwork were selected to

158 represent important migration evenings (suitable weather conditions and timing). Each evening,

159 at least 5 people took part in the search, regularly patrolling the road, and accordingly most

160 amphibians were found alive before or when entering the road. The road section searched was ca

$161950 \mathrm{~m}$ (same section before and after), therefore extending between and in both directions $\geq 100$

162 m outside of the mitigated sections. Customised infrared timelapse cameras (15s interval)

163 assembled by Froglife (Jarvis, Hartup \& Petrovan, 2019) were mounted on the ceiling inside of

164 the tunnel entrances; due to temporary failure of the IR light source, the total number of camera 
165 days acquired varied between 7 and 11 (Table 3). One of the tunnels (no. 5) was not monitored

166 because of a constant flow of water inside the tunnel, which was assumed to interfere with the

167 analysis of tunnel photos; however this tunnel was in place already before the mitigation system

168 was constructed, functioning as a drainage pipe, and it was therefore was not further considered

169 in the analyses. Position, species, status (e.g., dead/alive) and time were recorded for all

170 amphibian observations, both on the road, along fences and in the tunnels. For animals on tunnel

171 photos, movement direction (in or out) was noted and the minimum net number through the

172 tunnel was calculated. Significant numbers were found of 4 species (all except great crested

173 newt) so we included data on all amphibians, and we pooled the data on all species in the

174 analyses. Most amphibians found on or approaching the road were alive (ca 83\%).

175 Field methodology and data output for all three sites is described in further detail in technical

176 reports (in Swedish; Ekologigruppen, 2004; Syde, 2008; Collinder, 2010; Calluna, 2012;

177 Peterson, 2013a; 2013b; Andersson \& Lundberg, 2015; Helldin, 2015; Helldin, Olsson \&

178 Andersson, 2018).

\subsection{Data treatment and analyses}

180

181

182

183

184

185

186

187

188

189

190

191

192

193

194

We standardised the available data on amphibian counts on and near the roads, along fences and in tunnels to be able to compare, as far as possible, each site before and after mitigation and the mitigated road section with adjacent non-mitigated sections. We summarised the number of amphibians found on and near the road (including along temporary fences at site 2) per night (site 1) or evening (site 2-3) and 50m road interval, assuming that these data were collected with a similar effort and expertise over the road section searched, and with a similar effort and expertise before and after mitigation, within each site.

To be able to tentatively compare the performance of different tunnels at a site, we calculated the number through each tunnel per night (at site 1) or number of movements (in + out) and the net number through each tunnel per 24h-period (at site 2-3). To assess the number of amphibians successfully crossing a mitigated road section through the tunnels we summarised the net number through all tunnels at the site.

To assess the number of amphibians killed and the number successfully crossing a non-mitigated road section, we used the information presented by Hels \& Buchwald (2001) on the risk of getting killed for an amphibian on the road depending on average traffic intensity and species 
195 (Fig. 4). According to this relationship, a proportion of the amphibians attempting to cross a road 196 should make it successfully to the other side even without any mitigation, i.e.:

$197 x=1-y$

equation (1)

198 where $x$ is the number of successful crossings and $y$ is the risk of getting killed on the road.

199 Concomitantly, a number of amphibians found dead on the road should also represent a certain

200 number that survived and managed to cross, following:

$201 x=z(1 / y-1)$

equation (2)

202 where $x$ is the number of successful crossings, $z$ is the number of amphibians found dead on the

203

204

205

206

207

208

209

210

211

212

213

214

215

216

217

218

219

220

221

\section{6} road, and $y$ is the risk of getting killed on the road. Based on average traffic intensity at site 1, we estimated that $62 \%$ of newts trying to cross the road surface would be killed by traffic (as in Fig. 4), and that each newt found dead represented 0.61 newt that had managed to cross (following equation 2). Similarly, for site 2 we estimated a 70\% risk of traffic mortality for toads (Fig. 4), with each toad found killed representing 0.43 toads that had crossed successfully (equation 2) and each toad found along the temporary fence representing 0.30 toad that would have managed to cross the road, had the fence not been in place (equation 1). Finally, for site 3 we assumed that on average $75 \%$ of amphibians trying to cross the road surface would get killed by traffic (an estimate based on 79\% risk for newts, and 72\% risk for toads and frogs; Fig. 4) and that each amphibian rescued represented 0.25 amphibian that would have managed to cross the road, had the rescue not taken place (equation 1).

15

\section{Results}

The number of amphibians found on or heading for the road, i.e. animals killed or at risk of being killed by car traffic, during spring migration decreased at mitigated road sections at all 
222 three sites (Fig. 5). The estimated number of individual amphibians saved by the mitigation

223 measures ranged from 25 to $>200$ per night at the three sites (Table 3), corresponding to an 85-

$224100 \%$ decrease in amphibians killed on the road along mitigated road sections. Outside mitigated

225 sections, the changes from before to after mitigation installation were smaller and more variable;

226 the number of amphibians on the road decreased by $33 \%$ at site 1, increased by over $300 \%$ at site

227 2, while there was virtually no change at site 3 . At site 2, the number of amphibians on the road

228 peaked just outside of the fence-ends (intervals 8 and 15-17; see Fig. 5). At sites 1 and 2, some

229 individuals were found on the road just inside the fence-ends (east end at site 1, both ends at site

230 2; Fig. 5). No amphibians were found on a fenced road section $>100 \mathrm{~m}$ from a fence-end.

231 The number of amphibians passing through the tunnels varied greatly between sites (3000\%

232 difference; Table 4), generally in line with the numbers killed before mitigation, i.e., many more

233 at site 1 . The estimated number of amphibians successfully crossing the road increased at

234 mitigated sections, ranging from 2-164 more individuals per night (Table 5), corresponding to a

$23525-340 \%$ increase compared to the situation before mitigation. In addition, the estimated number

236 successfully crossing along non-mitigated sections differed before and after mitigation, and over

237 the entire site (mitigated + non-mitigated road sections combined) the mitigation implementation

238 resulted in 2-145 more individuals crossing the road per night (Table 5), or a 20-340\% increase.

239 The number of amphibians passing through the tunnels also varied greatly among the tunnels at

240 sites 1 and 3 (Table 4). Tunnel no. 2 at site 3 stood out by the large discrepancy between the high

241 number of amphibians moving in and out of the tunnel entrance and the low net number passing

242 through. This tunnel had a shallow pool in the northern (entrance) side, while the southern (exit)

243 side was completely submerged due to a construction fault.

The compiled results from the monitoring of amphibian passages at the three sites (Skårby, Kyrksjölöten, Skeppdalsström) indicate that the passages were effective in reducing amphibian roadkill during spring migration, compared to a situation before mitigation measures were implemented. None or very few amphibians were found on the fenced road sections, where prior 
251 are well in line with those from many other studies, showing significant reductions in amphibian

252 roadkill after the construction of adequate road fences (e.g., Meinig, 1989; Dodd, Barichivich \&

253 Smith, 2004; Jochimsen et al., 2004; Stenberg \& Nyström, 2009; Malt, 2011; Matos et al., 2017;

254 Matos et al., 2018; Hill et al., 2018; Jarvis, Hartup \& Petrovan, 2019).

255 However, the data from at least two of our sites suggested the presence of fence-end effects

256 (Huijser et al., 2016) which may influence the overall reduction in amphibian roadkill. Peaks in

257 numbers of amphibians on the road just outside fence-ends at site 2 suggest that some individuals

258 following the fence by-passed the final portions of fencing, despite the angled design, and that

259 part of the mortality was merely transferred from fenced to unfenced road sections. The increase

260 in amphibians on the entire unfenced part of the road at site 2 may also be explained by

261 individuals finding new migration routes when the previous ones have been occupied by fences,

262 while tunnels are avoided or simply not encountered (though we also see several alternative

263 explanations to that pattern; see below). Furthermore, at site 1 and site 2 some amphibians cut

264 into the mitigated road section near the fence-ends. This may be an effect of animals moving

265 diagonally over the road, not being strictly directional in their movements, or following the road

266 along curbs or other minor structures into the fenced section. Nearer to the middle of the fenced

267 sections, no amphibians were found on the road, and accordingly, in the central parts of the

268 mitigated road sections the decrease in roadkilled amphibians was $100 \%$ at all three sites.

269 These fence-end effects, and the fact that many amphibians crossed and were killed on the road

270 outside the fenced sections, imply that longer fences are likely to result in a larger reduction in

271 roadkill (Buck-Dobrik \& Dobrick, 1989; Huijser et al., 2016). While this notion may seem

272 trivial, it has important implications for management (see below).

273 It is imperative that the effectiveness of amphibian passages in the form of under-road tunnels

274 with associated guiding fences are not only assessed on the basis of the reduction in roadkill but

275 also on the number of animals making it successfully to the other side of the road (Jochimsen et

276 al., 2004; Schmidt \& Zumbach, 2008). Previous studies have indicated that many amphibians

277 reaching the fences do not find their way through the tunnels, either because the tunnels are too

278 widely separated or the tunnels or guiding structures are inadequate, and as a consequence

279 amphibians may return to the terrestrial habitats without breeding (Allaback \& Laabs, 2003;

280 Jochimsen et al., 2004; Schmidt \& Zumbach, 2008; Pagnucco et al., 2012, Hedrick et al., 2019). 
281 Several European studies have reported the overall rates of individual toads or newts using 282 tunnels ranging from 3\% to $98 \%$ of those encountering the guiding fences (Brehm, 1989; Buck283 Dobrick \& Dobrick, 1989; Langton, 1989; Meinig, 1989; Zuiderwijk, 1989; Mechura et al., 284 2012; Matos et al., 2017; Matos et al., 2018; Ottburg \& van der Grift, 2019; Jarvis, Hartup \& 285 Petrovan, 2019).

286 The results from our three sites indicated that the mitigation schemes likely reduced the barrier 287 effects of the roads. We assumed that even without mitigation in place, a certain proportion of 288 amphibians manage to cross a road without getting killed by traffic, that most amphibians 289 survive where the traffic intensity is very low, but that the proportion surviving decreases 290 exponentially with increasing traffic (Hels \& Buchwald, 2001; Gibbs \& Shriver, 2005; Jacobson 291 et al., 2016). Importantly however, on all three sites studied, the number of individuals passing through the tunnels in spring exceeded the number estimated to have crossed the road surface successfully over the mitigated section before the mitigation was in place.

294

295

296

297

298

299

300

301

302

303

304

305

306

307

308

309

310

Several factors in the technical construction of amphibian passages may affect their effectiveness: width, shape and length of tunnels, distance between tunnels, height and shape of guiding barriers, substrate in tunnels and along barriers, construction material, moisture, vegetation and drainage in and around the passages, special features such as cover objects, guiding structures at entrances and slotted tops (reviews in Jochimsen et al., 2004; Hamer, Langton \& Lesbarrères, 2015; Jackson, Smith \& Gunson, 2015). Our data did not allow a systematic analysis of how these factors relate to the passage effectiveness. With the information at hand, we can only speculate about the differences observed. At site 1, many newts were carried through the tunnels by the water running in direction towards the wetland, and at site 3 , standing water in one of the tunnels appeared to attract many amphibians to the tunnel entrance but blocked the tunnel for actual crossings. Shallow standing or running water in and around tunnels can attract amphibians and help them finding their way through (Rosell et al., 1997; Eriksson, Sjölund \& Andrén, 2000; Jochimsen et al., 2004; Schmidt \& Zumbach, 2008, Jarvis, Hartup \& Petrovan, 2019), but high water levels make tunnels impassable (Buck-Dobrick \& Dobrick, 1989; Rosell et al., 1997; Jochimsen et al., 2004). Water levels may thus have a significant, but complex, impact on amphibian passage effectiveness. Additionally, the water and soil inside and adjacent to amphibian tunnels can suffer high pollution levels from road surface 
311 contaminants including salt used for deicing roads as well as various metals and other substances

312 (White, Mayes \& Petrovan, 2017). At site 2, both the tunnels and the distance between them

313 were longer than at the other sites, which may explain a bypass effect, i.e., peaks in animals on

314 the road just outside fence-ends. Previous studies suggest that long tunnels and long fences

315 without tunnels make amphibians give up and turn back (Zuiderwijk, 1989; Jochimsen et al.,

316 2004; Jackson, Smith \& Gunson, 2015; Hill et al., 2018; Ottburg \& van der Grift, 2019; Matos et

317 al., 2018); these individuals may eventually try crossing the road on another spot. There were

318 substantial movements in and out of the tunnels at this site, which may also indicate that animals

319 hesitated to pass through. However, the total numbers actually crossing through the tunnels were

320 broadly similar to the estimated number killed or crossing the fenced section before mitigation

$321(58.8 / 24 \mathrm{~h}$ versus $32.1+13.8=45.9 /$ night $)$.

322 There are several plausible explanations for the changes in the number of amphibians on the road

323 outside mitigated sections (most pronounced at site 1 and 2), other than the potential bypass

324 effect described above. The most obvious is that the field effort at some sites and time periods

325 was insufficient (three nights or less for data collection) and the data therefore were influenced

326 by random events. Another is that the fieldwork methods were in fact not similar enough with

327 regard to how the basic method was applied in practice to allow the data standardisation and

328 comparisons. The changes observed may also depend on annual differences in population

329 numbers or temporal migration patterns. In this case, the effect sizes on mitigated sections can be

330 adjusted according to the changes on non-mitigated sections. It is however important to note that

331 the non-mitigated sections studied were not true controls (comparators), as they may have been

332 affected by the mitigation measure (the intervention).

333 The standardisation of data required a number of assumptions and simplifications that may have

334 introduced errors. We adopted an approach where we tried finding the unifying patterns in

335 studies of amphibian passages conducted with slightly different aims, budgets, staffing and time

336 frames. Despite these limitations, which are unfortunately common in applied conservation

337 projects, we believe that the general picture given by these studies, before versus after mitigation

338 and along versus outside the mitigated road section, contributes significantly to the knowledge of

339 how amphibian passages at roads can reduce roadkill and barrier effects on amphibians during

340 spring migration.

Peer) reviewing PDF | (2019:04:36340:2:0:NEW 17 Jul 2019) 
342 There is scant evidence in literature that amphibian passages lead to long-term conservation of 343 amphibian populations (Beebee, 2013; Smith, Meredith \& Sutherland, 2018, Jarvis, Hartup \& 344 Petrovan, 2019), and for our three sites it is difficult to be certain to what degree the observed reductions in roadkill and barrier effect will have a significant and long-lasting effect on the population level. However, the estimated number of newts saved by the mitigation system $(>200$ individuals per peak migration night) and the number of newts crossing through the tunnels (ca 180 per peak migration night) at site 1 (Skårby) are each in the same order of magnitude as the total estimated number of breeding newts at the site (2,000-2,300 individuals, assuming that there are around 10 peak migration nights per season; Peterson \& Collinder, 2006).

351 By contrast, the low number of amphibians successfully crossing through the tunnels at site 3 (Skeppdalsström) - ca 10 individuals per night, an increase with only 2 per night compared to

353

354 what may have crossed the road successfully without any mitigation - may appear discouraging. The reduction in the number killed (some 25 per peak migration night) sums up to nowhere near the total estimated number of amphibians breeding at the site (ca 1,300 individuals; Andersson \& Lundberg 2015). The results from site 2 (Kyrksjölöten) indicate that many more toads manage to cross the road alive using the tunnels compared to before mitigation, but these results cannot be put in relation to any estimated population size, and the conclusion regarding the benefit to conservation is confused by the possible bypass effects (see above).

It is important to point out that there should be a minimal level of road traffic where amphibian passages of the kind described here need to be considered, as implied by the relationship between traffic intensity and risk of getting killed described by Hels \& Buchwald (2001; Fig. 4). On roads with low traffic many amphibians are likely to cross the road without getting killed, and an amphibian passage with fences that hinders some of these movements may lead to a decrease in the number of successful crossings, and accordingly cause more harm than good (Jaeger \& Fahrig, 2004; Jochimsen et al., 2004; Schmidt \& Zumbach, 2008; Pagnucco et al., 2012). The cut-off point depends on the combination of traffic intensity and effectiveness of passages.

All data treatment in our work relies heavily on Hels \& Buchwald's (2001) risk model for amphibians. While that study was well conducted, the results were based on few species and 
370 limited observations, and empirical tests of the model prediction are still rare (Gibbs \& Shiver,

371 2005). Given the need for road managers to know under what circumstances the construction of

372 amphibian passages is motivated, and when not, we strongly recommend further study of the

373 relation between road characteristics (traffic, width etc.) and the roadkill risk for amphibians

374 when attempting to cross.

375 At all three sites the mitigation was restricted solely to the most critical road sections (see Fig.

376 5), despite recommendations in ecological assessments from all sites to include also contiguous

377 sections (Collinder, 2007; Helldin, 2015; Lundberg, 2015). Our results suggest that mitigation

378 (guiding fences and additional tunnels) extending at least some $100 \mathrm{~m}$ outside of the most critical

379 road section could minimise fence-end effects and further improve the passage effectiveness.

380 An alternative approach to decrease fence-end effect could be to fortify fence-ends, for example

381 by modifying the angles or extending fences perpendicularly from the road, compared to what

382 was done at our sites 2 and 3 (Fig. 3D, F). Amphibians could potentially be helped in finding and

383 entering tunnels with relatively simple means by installing guiding structures at the tunnel

384 entrances where these are not already in place (site 3). It is however unclear to what degree such

385 adaptations would improve the effectiveness of existing passages.

386 Amphibian passages tend to be costly, not least when constructed on existing roads, and it is

387 therefore crucial for road managers to know where passages may be critical for amphibian

388 conservation and how passages can best be designed. To build up the knowledge of amphibian

389 passages at roads, the reduction in roadkill and barrier effects should be monitored when new

390 amphibian passages are constructed, or when existing passages are adapted (Hamer, Langton \&

391 Lesbarrères, 2015; Helldin, 2017). The monitoring should use comparable methods before and

392 after mitigation, include the quantification of amphibians killed and amphibians successfully

393 crossing, over a long enough road section to cover bypass effects. Quality data should be secured

394 by a field effort spanning over multiple years before and after mitigation, and multiple times

395 each year. Results from such studies could be combined in regional and global analyses (e.g.,

396 meta-analyses) to explore differences between construction types and trade-offs between the

397 economic investment and expected effect size (cost-efficiency), thereby helping to point out

398 where passages along existing roads are warranted. 
399 Finally, it is important to note that our results only focused on adult breeding migrations in

400 spring, without including the summer and autumn migrations of juveniles away from the

401 breeding ponds. Recent population models indicate that the survival of post-metamorphic

402 juveniles is of fundamental importance for the persistence of amphibian populations (Schmidt \&

403 Zumbach, 2008; Petrovan \& Schmidt, 2019). Adults and juveniles using the passages later in the 404 season, when leaving the breeding areas, may experience dryer tunnels or even water

405 counterflow. Juvenile amphibians may be particularly sensitive to the design of underpasses and

406 associated barrier fences (Schmidt \& Zumbach, 2008) given their higher desiccation risk.

407 However, due to their very small size and unpredictable migration timing, juveniles remain very 408 rarely quantified in terms of both road mortality impacts and usage of mitigation systems, despite 409 their crucial role in population dynamics (Petrovan \& Schmidt, 2019). Future studies should 410 prioritise incorporating juveniles in mitigation assessments.

411

412

\section{Acknowledgements}

413

414

415

416

417

418

419

420

421

422

423

424

425

We thank the following people for collecting and processing field data used in the study: Petter Andersson, Per Collinder, Abel Gonzales, Michael Hartup, Mova Hebert, Anna Koffman, Johanna Lundberg, Terese Olsson, Torbjörn Peterson, Anna Seffel, Lisa Sigg, Nina Syde, Claes Vernerback and Mikael Åsberg. We are particularly grateful to Per Collinder for digging out old Skårby reports, and to all the volunteers at Djurens Ö Wildlife Rescue for backing up the field work at Skeppdalsström. We thank Lars Nilsson, Edgar van der Grift, Brandon Hedrick and Richard Griffiths for reading and commenting on previous versions of this paper.

\section{References}

Allaback ML, Laabs DM. 2002. Effectiveness of road tunnels for the Santa Cruz long-toed salamander. Transactions of the Western Section of the Wildlife Society 38/39:5-8.

Andersson P, Lundberg J. 2015. Groddjursinventering och flytt vid väg 222, Skeppdalsström, Värmdö kommun, Stockholms län. Report from Trafikverket dated 2015-06-10. (In 
Swedish) http://media.triekol.se/2019/03/Andersson-Lundberg-2015-Groddjursinventeringoch-flytt-vid-vag-222.pdf

Banverket. 2005. Vilda djur och infrastruktur - en handbok för åtgärder. Banverket Miljösektionen rapport 2005:5, Vägverket publikation 2005:72. (In Swedish) https://trafikverket.ineko.se/Files/svSE/12025/RelatedFiles/2005 72 vilda djur_och infrastruktur_en handbok for_atgarder.pd $\underline{f}$

Beebee TJC. 2013. Effects of road mortality and mitigation measures on amphibian populations. Conservation Biology 27(4):657-668. https://doi.org/10.1111/cobi.12063

Bonardi A, Manenti R, Corbetta A, Ferri V, Fiacchini D, Giovine G, Macchi S, Romanazzi E, Soccini C, Bottoni L, Padoa-Schioppa E, Ficetola GF. 2011. Usefulness of volunteer data to measure the large scale decline of "common" toad populations. Biological Conservation 144:2328-2334.

Brehm K. 1989. The acceptance of 0.2-metre tunnels by amphibians during their migration to the breeding site. In: Langton TES, ed. Toad Tunnel Conference: Amphibians and Roads. Proceedings of the Toad Tunnel Conference, Rendsburg, Federal Republic of Germany, 7-8 January 1989, 29-42.

Buck-Dobrick T, Dobrick R. 1989. The behaviour of migrating anurans at a tunnel and fence system. In: Langton TES, ed. Toad Tunnel Conference: Amphibians and Roads. Proceedings of the Toad Tunnel Conference, Rendsburg, Federal Republic of Germany, 7-8 January 1989, 137-143.

Calluna. 2012. Groddjursinventering; Undersökning av vandringsmönster inför anläggning av groddjurstunnlar utmed Spångavägen vid Kyrksjölötens naturreservat. Report from Calluna $A B$ and Trafikkontoret, Stockholms Stad. (In Swedish) http://miljobarometern.stockholm.se/content/docs/tema/natur/Groddjur/Groddjursrapport_Sp angavagen121219_Lagupplost.pdf

Collinder P. 2007. Skårby åtgärdsförslag. Report from Ekologigruppen AB 2007-07-04. (In Swedish) http://media.triekol.se/2019/03/Collinder-2007-Skarby-Atgardsforslag.pdf

Collinder P. 2010. Groddjursinventering 2010 vid konfliktpunkter i Stockholms län. Report from Ekologigruppen AB August 2010. (In Swedish) http://media.triekol.se/2019/03/Collinder2010-Groddjursinventering-2010-vid-konfliktpunkter-i-Stockholms-lan.pdf

de Maynadier PG, Hunter Jr ML. 2000. Road effects on amphibian movements in a forested landscape. Natural Areas Journal 20(1):56-65.

Dodd CK, Barichivich WJ, Smith LL. 2004. Effectiveness of a barrier wall and culverts in reducing wildlife mortality on a heavily traveled highway in Florida. Biological Conservation 118:619-631. 
462

463

464

465

466

467

468

469

470

471

472

473

474

475

476

477

478

479

480

481

482

483

484

485

486

487

488

489

490

491

492

493

494

495

496

497

Ekologigruppen. 2004. Utredning av behov av groddjurspassage vid Skårbydammen. Report from Ekologigruppen AB 2004-05-06. (In Swedish) http://media.triekol.se/2019/03/Ekologigruppen-2004-Utredning-Skarby.pdf

Eriksson O, Sjölund A, Andren C. 2000. Amphibians and roads. Swedish National Road Administration Publication 7, Vägverket, Borlänge, Sweden.

Faggyas S, Puky M. 2012. Construction and preliminary monitoring results of the first ACO Wildlife Pro amphibian mitigation systems on roads in Hungary. Állattani Közlemények 97:85-93. http://real-j.mtak.hu/8022/1/AllataniKozlemenyek 97.pdf (In Hungarian, with English summary)

Fahrig L, Rytwinski T. 2009. Effects of roads on animal abundance: an empirical review and synthesis. Ecology and society 14(1):21.

Gibbs JP, Shriver WG. 2005. Can road mortality limit populations of pool-breeding amphibians? Wetlands Ecology and Management 13:281-289.

Hamer AJ, Langton TES, Lesbarrères D. 2015. Making a safe leap forward: Mitigating road impacts on amphibians. In: van der Ree R, Smith DJ, Grilo C, eds. Handbook of Road Ecology, First Edition. John Wiley \& Sons Ltd, 261-270.

Hedrick BP, Vander Linden A, Watt E, O'Roark PM, Cordero SA, Sutherland C. 2019. Keeping salamanders off the streets: An assessment of one of the first amphibian road tunnels in the United States 30 years after installation. Preprint at bioRxiv https://doi.org/10.1101/569426

Helldin JO. 2015. Uppföljning och utvärdering av groddjurstunnlar på Spångavägen. Report from Calluna $A B$ and Stockholm Stad. (In Swedish)

http://miljobarometern.stockholm.se/content/docs/tema/natur/Groddjur/Groddjurstunnlar\%2 0Spångavägen\%20Rapport\%202015-10-02.pdf

Helldin J-O. 2017. Metod för uppföljning av groddjursåtgärder vid väg. Trafikverket publikation 2017:130. (In Swedish.) https://trafikverket.ineko.se/se/metod-f\%C3\%B6ruppf\% $\%$ C3\%B6ljning-av-groddjurs $\% \mathrm{C} 3 \% \mathrm{~A} 5 \operatorname{tg} \% \mathrm{C} 3 \% \mathrm{~A} 4$ rder-vid-v\% $\% 3 \% \mathrm{~A} 4 \mathrm{~g}$

Helldin JO, Olsson T, Andersson P. 2018. Uppföljning och utvärdering av groddjursåtgärder vid Skeppdalsström - G178, Värmdö kommun. Trafikverket report 2018:232. (In Swedish) https://trafikverket.ineko.se/Files/sv-

SE/57352/Ineko.Product.RelatedFiles/2018_232_uppfoljning_och_utvardering_av_groddjur satgarder_vid_skeppdalsstrom.pdf

Hels T, Buchwald E. 2001. The effect of road kills on amphibian populations. Biological Conservation 99:331-340.

Hill IDC, Rossi CA, Petrovan SO, Hartup M, Clark F, Downie JR. 2018. Mitigating the effects of a road on amphibian migrations: a Scottish case study of road tunnels. The Glasgow Naturalist 27, Supplement: The Amphibians and Reptiles of Scotland. 
498

499

500

501

502

503

504

505

506

507

508

509

510

511

512

513

514

515

516

517

518

519

520

521

522

523

524

525

526

527

528

529

530

531

532

533

Huijser MP, Fairbank ER, Camel-Means W, Graham J, Watson V, Basting P, Becker D. 2016. Effectiveness of short sections of wildlife fencing and crossing structures along highways in reducing wildlife-vehicle collisions and providing safe crossing opportunities for large mammals. Biological Conservation 197:61-68.

Iuell B, Bekker HGJ, Cuperus R, Dufek J, Fry G, Hicks C, Hlaváč V, Keller V, Rosell C, Sangwine T, Tørsløv N, Le Maire Wandall B. 2003. COST 341-Wildlife and Traffic: a European handbook for identifying conflicts and designing solutions. KNNV Publishers, Brussels. http://www.iene.info/wp-content/uploads/COST341_Handbook.pdf

Jarvis LE, Hartup M, Petrovan SO. 2019. Road mitigation using tunnels and fences promotes site connectivity and population expansion for a protected amphibian. European Journal of Wildlife Research 65:27.

Jackson SD, Smith DJ, Gunson K. 2015. Mitigating road effects on small mammals. In: Andrews KM, Nanjappa P, Riley SPD, eds. Roads and Ecological Infrastructure; Concepts and Applications for Small Animals, John Hopkins University Press, Baltimore, 177-207.

Jacobson SL, Bliss-Ketchum LL, de Rivera CE, Smith WP. 2016. A behavior-based framework for assessing barrier effects to wildlife from vehicle traffic volume. Ecosphere 7(4):e01345. $10.1002 /$ ecs 2.1345

Jaeger JAG, Fahrig L. 2004. Effects of road fencing on population persistence. Conservation Biology 18:1651-1657. DOI10.1111/j.1523-1739.2004.00304.x

Jochimsen DM, Peterson CR, Andrews KM, Whitfield Gibbons J. 2004. A literature review of the effects of roads on amphibians and reptiles and the measures used to minimize those effects. Idaho Fish and Game Department and USDA Forest Service report.

Kyek M, Kaufmann PH, Lindner R. 2017. Differing long term trends for two common amphibian species (Bufo bufo and Rana temporaria) in alpine landscapes of Salzburg, Austria. PLoS ONE 12(11): e0187148. https://doi.org/10.1371/journal.pone.0187148

Langton TES. 1989. Tunnels and temperature: results from a study of a drift fence and tunnel system for amphibians at Henley-on-Thames, Buckinghamshire, England. In: Langton TES, ed. Toad Tunnel Conference: Amphibians and Roads. Proceedings of the Toad Tunnel Conference, Rendsburg, Federal Republic of Germany, 7-8 January 1989, 145-152.

Langton TES. 2015. A history of small animal road ecology. Roads and ecological infrastructure: Concepts and applications for small mammals. In: Andrews KM, Nanjappa P, Riley SPD, eds. Roads and Ecological Infrastructure; Concepts and Applications for Small Animals. John Hopkins University Press, Baltimore, 7-20.

Lundberg J. 2015. PM Rekommendationer inför anläggande av groddjurstrummor, väg 222, vid Skeppdalsström. Report from Calluna AB 2015-02-13. (In Swedish) http://media.triekol.se/2019/03/Lundberg-2015-Rekommendationer-inför-anläggande.pdf 
534

535

536

537

538

539

540

541

542

543

544

545

546

547

548

549

550

551

552

553

554

555

556

557

558

559

560

561

562

563

564

565

566

567

568

569

570

571

Malt J. 2011. Assessing the effectiveness of amphibian mitigation on the Sea to Sky Highway: passageway use, roadkill mortality, and population level effects. Herpetofauna and Roads Workshop - Is there light at the end of the tunnel? Vancouver Island University, Nanaimo, Canada, 17-18.

Matos C, Petrovan S, Ward AI, Wheeler P. 2017. Facilitating permeability of landscapes impacted by roads for protected amphibians: patterns of movement for the great crested newt. PeerJ 5:e2922; DOI 10.7717/peerj.2922

Matos C, Petrovan SO, Wheeler PM, Ward AI. 2019. Short-term movements and behaviour govern the use of road mitigation measures by a protected amphibian. Animal Conservation 22:285-296. https://doi.org/10.1111/acv.12467

Mechura T, Gémesi D, Szövényi G, Puky M. 2012. Temporal characteristics of the spring amphibian migration and the use of the tunnel-barrier system along the Hont and Parassapuszta section of the main road No. 2. between 2009 and 2011. Allattani Közlemények 97:77-84. http://real-j.mtak.hu/8022/1/AllataniKozlemenyek 97.pdf (In Hungarian, with English summary)

Meinig H. 1989. Experience and problems with a toad tunnel system in the Mittelgebirge region of West Germany. In: Langton TES, ed. Toad Tunnel Conference: Amphibians and Roads. Proceedings of the Toad Tunnel Conference, Rendsburg, Federal Republic of Germany, 7-8 January 1989, 59-66.

Nyström P, Hansson J, Månsson J, Sundstedt M, Reslow C, Broström A. 2007. A documented amphibian decline over 40 years: possible causes and implications for species recovery. Biological Conservation 138:399-411.

Ottburg FGWA, van der Grift EA. 2019. Effectiveness of road mitigation for common toads (Bufo bufo) in the Netherlands. Frontiers in Ecology and Evolution 7:23.doi: $10.3389 /$ fevo.2019.00023

Pagnucco KS, Paszkowski CA, Scrimgeour GJ. 2012. Characterizing movement patterns and spatio-temporal use of under-road tunnels by long-toed salamanders in Waterton Lakes National Park, Canada. Copeia 2012(2):331-340.

Peterson T. 2013a. Utvärdering av grodtunnlar vid Skårbydammen, Salem våren 2013. Report from Trafikverket, ärendenummer TRV 2013/5489. (In Swedish) http://media.triekol.se/2019/03/Peterson-2013-Utvardering-av-grodtunnlar-i$\underline{\text { Skarbydammen.pdf }}$

Peterson T. 2013b. Utredning av groddjursvandring över väg 222 vid Skeppdalsström. Report from Trafikverket, ärendenummer TRV 2013/5489. (In Swedish) http://media.triekol.se/2019/03/Peterson-2013-Utredning-inför-grodtunnlar-vid$\underline{\text { Stavnasvagen.pdf }}$

Peterson T, Collinder P. 2006. Utvärdering av grodtunnlar vid Skårbydammen, Salem våren 2006. Report from Ekologigruppen AB. (In Swedish) 
572

573

574

575

576

577

578

579

580

581

582

583

584

585

586

587

588

589

590

591

592

593

594

595

596

597

598

599

600

601

602

603

604

605

606

607

608

609

\section{http://media.triekol.se/2019/03/Ekologigruppen-2006-Utvardering-av-grodtunnlar-vid-} $\underline{\text { Skarbydammen.pdf }}$

Petrovan SO, Schmidt BR. 2016. Volunteer conservation action data reveals large-scale and long-term negative population trends of a widespread amphibian, the common toad (Bufo bufo). PLoSONE 11(10):e0161943.doi:10.1371/ journal.pone.0161943.

Petrovan SO, Schmidt BR. 2019. Neglected juveniles; a call for integrating all amphibian life stages in assessments of mitigation success (and how to do it). Biological Conservation 236: 252-260.

Puky M, Vogel Z. 2003. Amphibian mitigation measures on Hungarian roads: design, efficiency, problems and possible improvement, need for a co-ordinated European environmental education strategy. International Conference on Habitat Fragmentation due to Transportation Infrastructure, IENE, Brussels, Belgium.

Rosell C, Parpal J, Campeny R, Jové S, Pasquina A, Velasco JM. 1997. Mitigation of barrier effect on linear infrastructures on wildlife. In: Habitat Fragmentation \& Infrastructure. Proceedings of the International Conference on Habitat Fragmentation, Infrastructure and the role of Ecological Engineering, 17-21 September 1995, Maastricht and The Hague, Netherlands. Ministry of Transport, Public Works and Water Management, Delft, Netherlands, 367-372.

Schmidt BR, Zumbach S. 2008. Amphibian road mortality and how to prevent it: a review. In: Mitchell JC, Jung Brown RE, Bartolomew B, eds. Urban Herpetology. St. Louis, Missouri, 157-167.

Smith RK, Meredith H, Sutherland WJ. 2018. Amphibian conservation. In: Sutherland WJ, Dicks LV, Ockendon N, Petrovan SO, Smith RK, eds. What Works in Conservation 2018. Open Book Publishers, Cambridge, UK, 9-65. https://www.openbookpublishers.com/product/696

Stenberg M, Nyström P. 2009. Uppföljning av åtgärder för groddjur i Skåne år 2009. Trafikverket report 2010:115. (In Swedish) https://trafikverket.ineko.se/Files/svSE/12192/RelatedFiles/2010 115 uppfoljning_av_atgarder for_groddjur_i skane ar_2009. pdf

Syde N. 2008. Groddjursinventering vid konfliktpunkter i Stockholms län. Report from Ekologigruppen AB. (In Swedish) http://media.triekol.se/2019/03/Syde-2008$\underline{\text { Groddjursinventering-vid-konfliktpunkter-i-Stockholms-lan.pdf }}$

White KJ, Mayes WM, Petrovan SO. 2017. Identifying pathways of exposure to highway pollutants in great crested newt (Triturus cristatus) road mitigation tunnels. Water and Environment Journal 31(3):310-316.

Zuiderwijk A. 1989. Amphibian and reptile tunnels in the Netherlands. In: Langton TES, ed. Toad Tunnel Conference: Amphibians and Roads. Proceedings of the Toad Tunnel Conference, Rendsburg, Federal Republic of Germany, 7-8 January 1989, 67-74. 
Figure 1

Location of the three study sites in Stockholms larger metropolitan area.

Map image credit: Lantmäteriet.

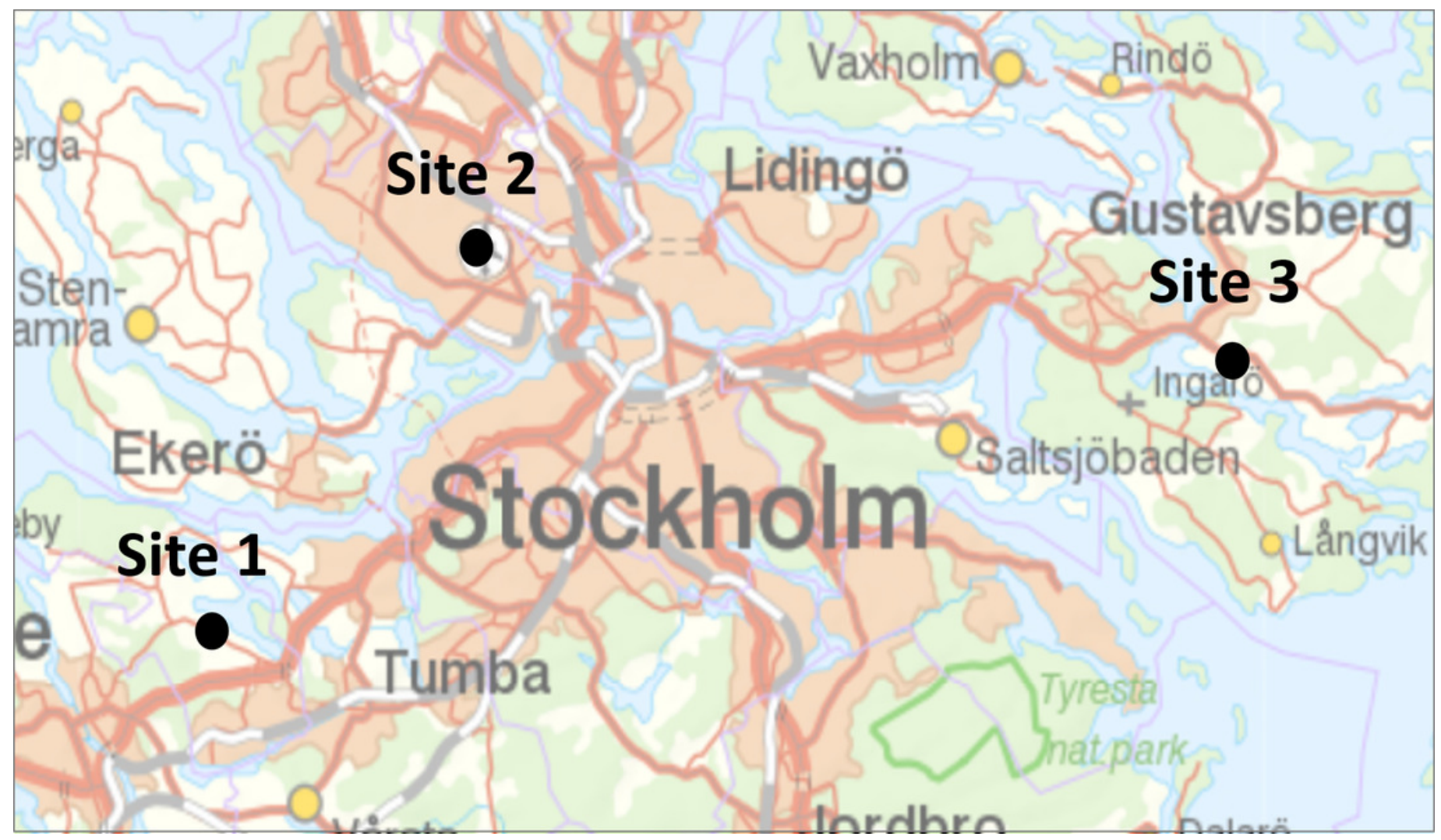


Figure 2

Maps of the three study sites.

Red lines denote mitigated (fenced) section, black lines are the tunnels, and blue line is the road section where amphibians were counted before and after mitigation. Map image credit: Lantmäteriet. 


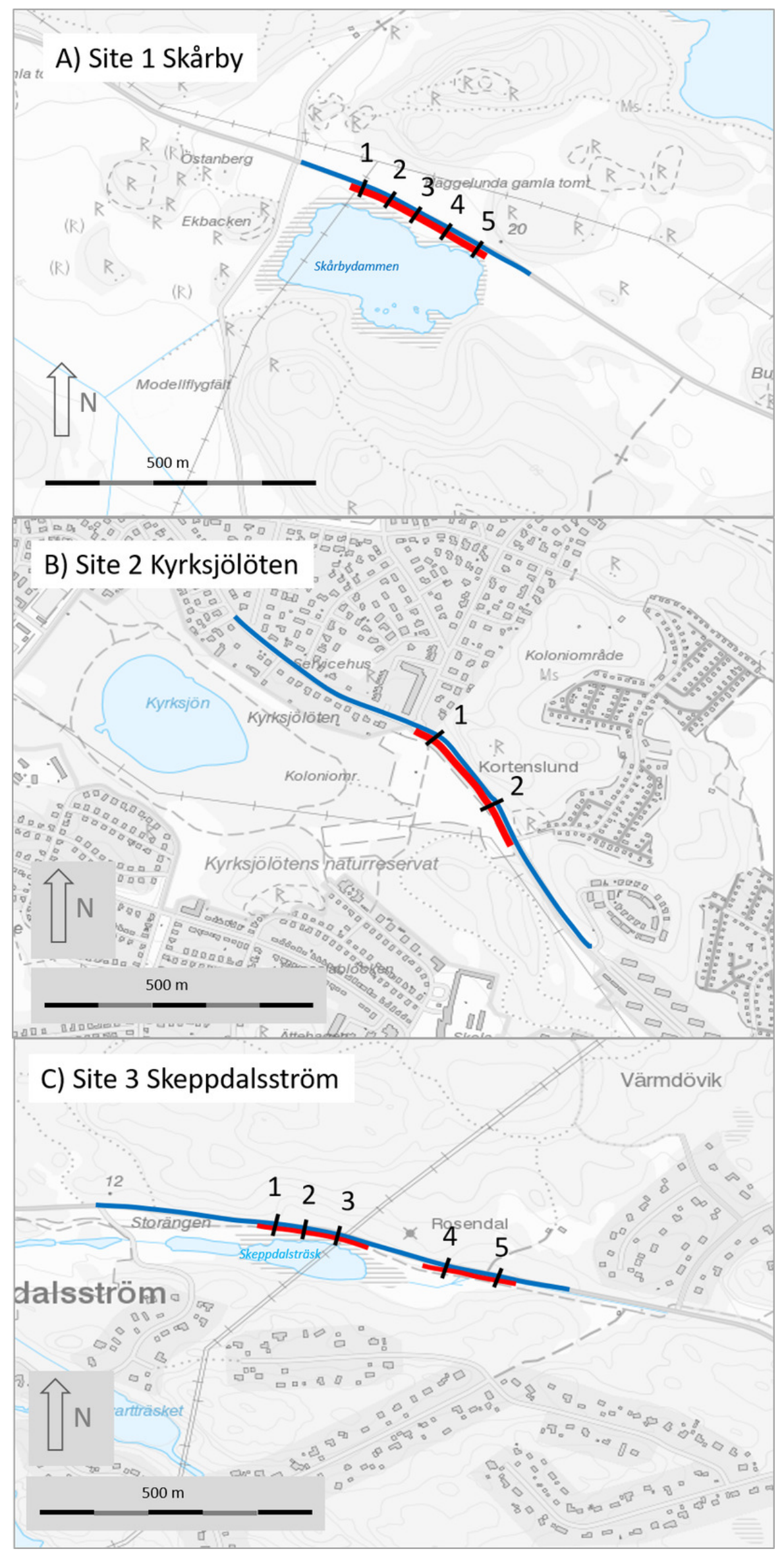


Figure 3

Amphibian tunnel with guiding structure, fence and fence-end at the three study sites.

Photos: Jan Olof Helldin and Erik Jondelius. 


\section{Site 1 Skårby}

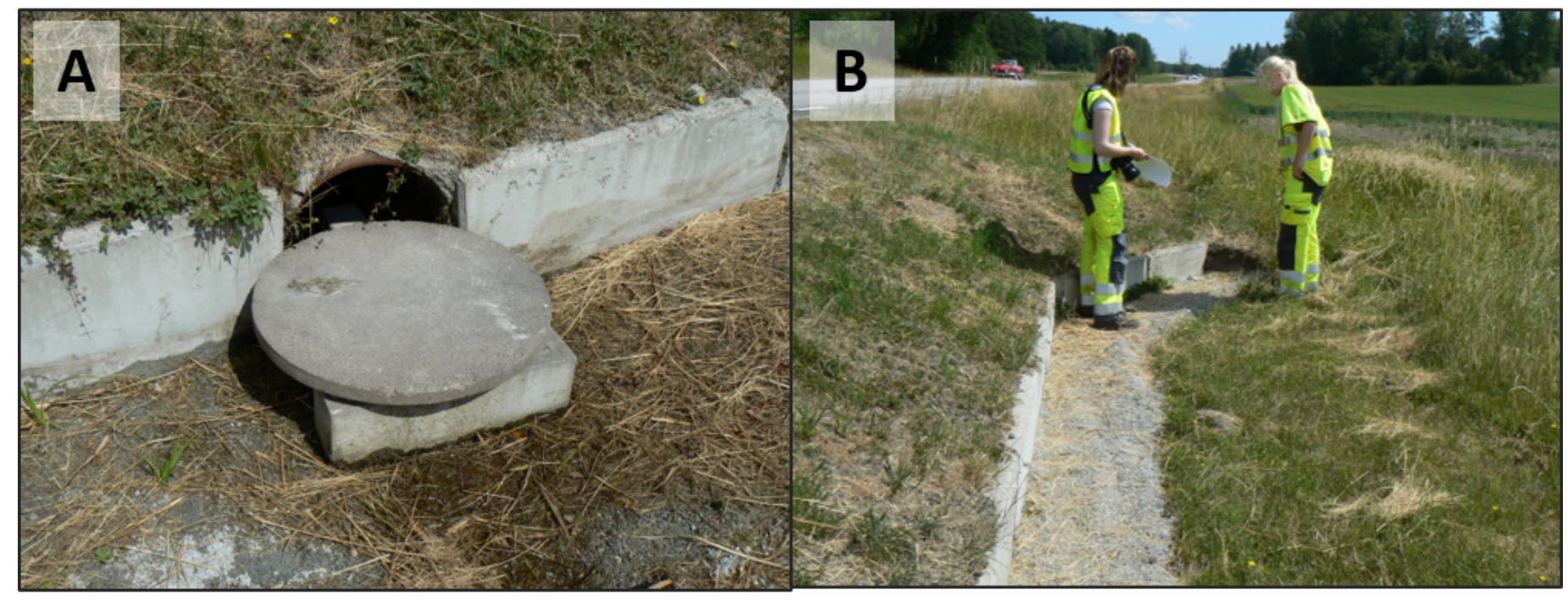

Site 2 Kyrksjölöten

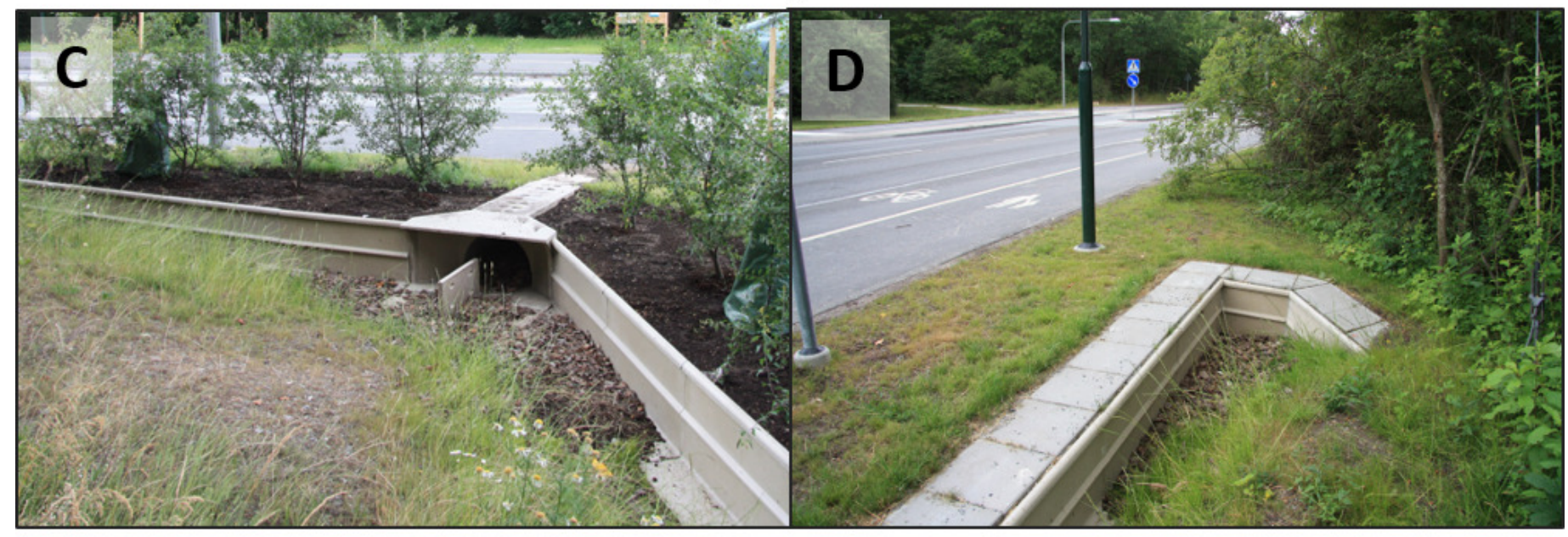

Site 3 Skeppdalsström

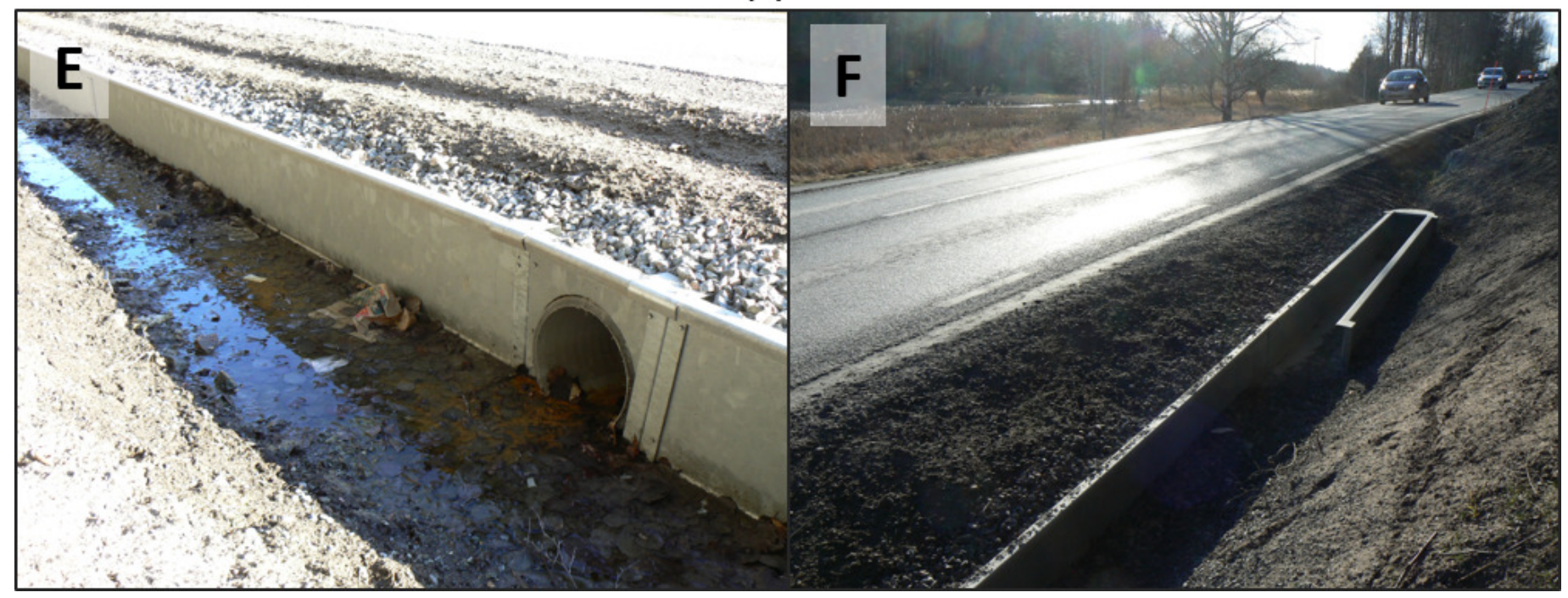




\section{Figure 4}

Probability of getting killed for an individual of different amphibian species at different traffic intensities, as described by Hels \& Buchwald (2001).

The probability of getting killed is weighted by amphibian behaviour (velocity and diurnal activity) and diurnal variation in traffic intensity, and assuming that amphibians are crossing perpendicular to the road. Traffic intensity of the three study sites are indicated by vertical dashed lines.

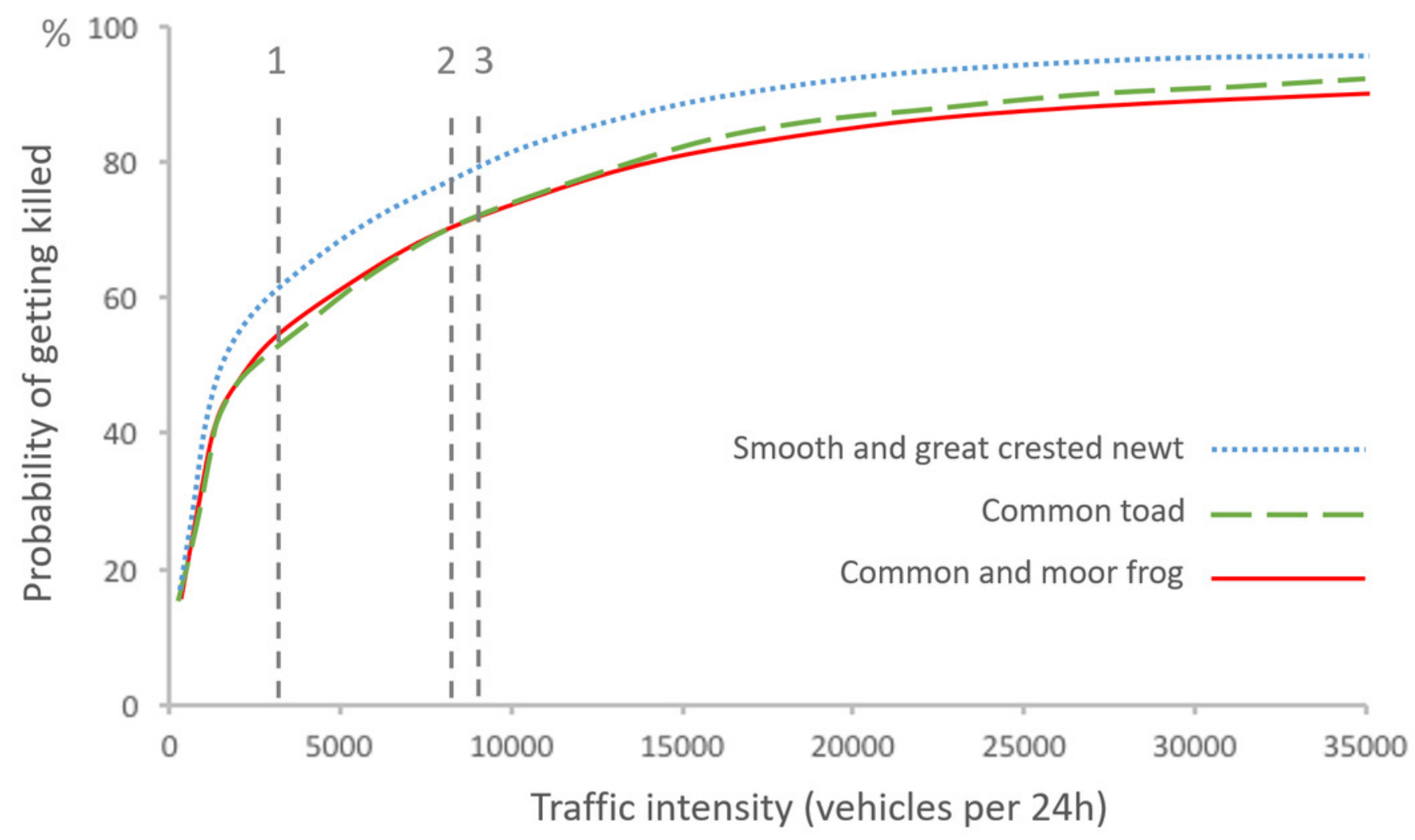




\section{Figure 5}

The number of amphibians found along the studied road sections, divided per evening or night and $50 \mathrm{~m}$ road interval starting from northwest.

Upper graphs $(A-C)$ are before mitigation, lower graphs (D-F) are with mitigation in place. Site 1: Number of dead newts (smooth + great crested) found per night; Site 2: Number of live and dead common toads found per night; Site 3: Number of live and dead amphibians (four species) found per evening. Red lines below $\mathrm{x}$-axes after mitigation denote the mitigated sections (permanent amphibian fencing), green line below $x$-axis at site 2 before mitigation denotes the temporary fenced section. Due to the difference in method, the data from counts along the temporary fence at site 2 cannot be directly compared to the other data from that site.

Site 1

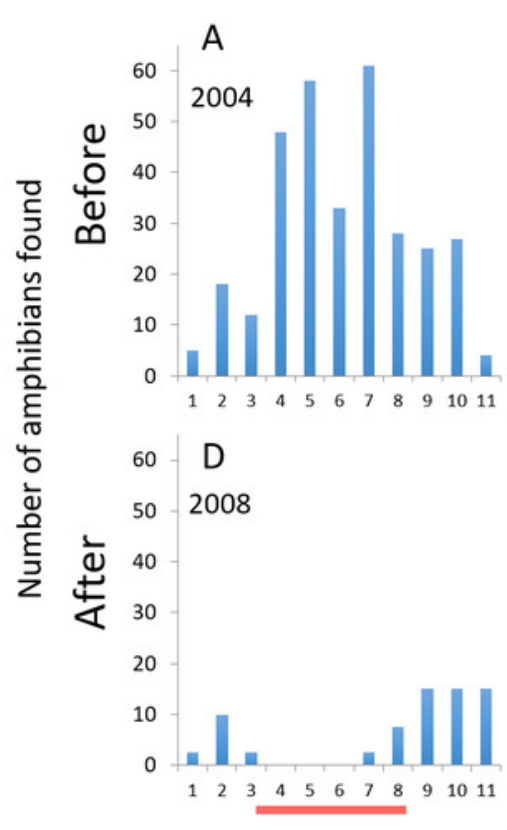

Site 2
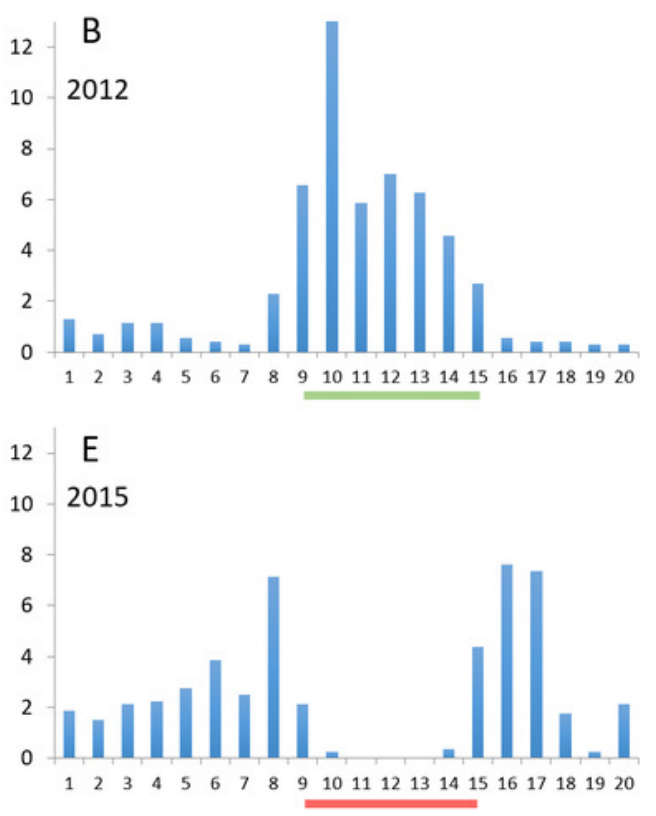

Site 3

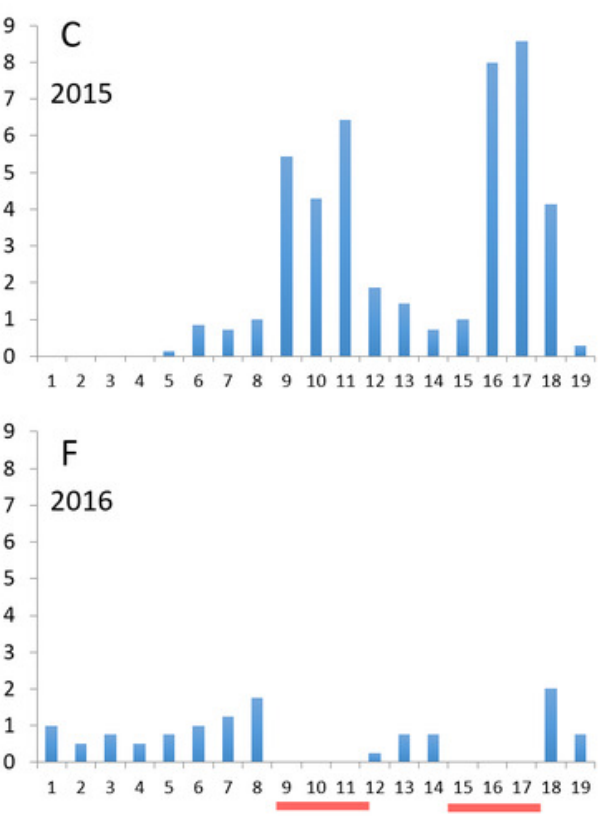




\section{Table $\mathbf{1}$ (on next page)}

Characteristics of the roads and the amphibian mitigation measures at the three study sites near Stockholm, Sweden.

Data on individual tunnels are listed from east to west (see Fig. 2). 
1 Table 1. Characteristics of the roads and the amphibian mitigation measures at the three study 2 sites near Stockholm, Sweden. Data on individual tunnels are listed from east to west (see Fig. 3 2).

\begin{tabular}{|c|c|c|c|c|c|c|c|c|c|c|c|c|}
\hline Site & \multicolumn{5}{|c|}{ 1. Skårby } & \multicolumn{2}{|c|}{ 2. Kyrksjölöten } & \multicolumn{5}{|c|}{ 3. Skeppdalsström } \\
\hline Location & \multicolumn{5}{|c|}{$59^{\circ} 13^{\prime} 34 \mathrm{~N} 17^{\circ} 43^{\prime} 55 \mathrm{E}$} & \multicolumn{2}{|c|}{$59^{\circ} 20^{\prime} 53 \mathrm{~N} 17^{\circ} 55^{\prime} 35 \mathrm{E}$} & \multicolumn{5}{|c|}{$59^{\circ} 18^{\prime} 16 \mathrm{~N} 18^{\circ} 29^{\prime} 32 \mathrm{E}$} \\
\hline $\begin{array}{l}\text { Construction year of } \\
\text { mitigation measure }\end{array}$ & \multicolumn{5}{|c|}{$\begin{array}{l}\text { 2005, additional tunnels } \\
\text { in } 2008\end{array}$} & \multicolumn{2}{|c|}{2014} & \multicolumn{5}{|c|}{2015} \\
\hline \multicolumn{13}{|l|}{ Road } \\
\hline Name/no & \multicolumn{5}{|c|}{ Road 584} & \multicolumn{2}{|c|}{ Spångavägen } & \multicolumn{5}{|c|}{ Road 222} \\
\hline Owner/manager & \multicolumn{5}{|c|}{$\begin{array}{c}\text { Swedish Transport } \\
\text { Administration }\end{array}$} & \multicolumn{2}{|c|}{$\begin{array}{c}\text { Stockholm } \\
\text { Municipality }\end{array}$} & \multicolumn{5}{|c|}{$\begin{array}{c}\text { Swedish Transport } \\
\text { Administration }\end{array}$} \\
\hline Mitigated section (m) & \multicolumn{5}{|c|}{300} & \multicolumn{2}{|c|}{315} & \multicolumn{5}{|c|}{$190+110$} \\
\hline Traffic (daily average) ${ }^{a}$ & \multicolumn{5}{|c|}{3,000} & \multicolumn{2}{|c|}{7,800} & \multicolumn{5}{|c|}{8,600} \\
\hline Width $(\mathrm{m})$ & \multicolumn{5}{|c|}{7} & \multicolumn{2}{|c|}{$16^{b}$} & \multicolumn{5}{|c|}{7} \\
\hline \multicolumn{13}{|l|}{ Guiding fences (barriers) } \\
\hline Height & \multicolumn{5}{|c|}{40} & \multicolumn{2}{|c|}{45} & \multicolumn{5}{|c|}{40} \\
\hline Material & \multicolumn{5}{|c|}{ Cement concrete } & Polyn & crete & & & Meta & & \\
\hline Sides & & & uble s & sided & & Do & ed & & Do & uble s & ed & \\
\hline Location & & Par & Ilel tc & o roa & & Para & oad & & Par & Ilel to & road & \\
\hline End & & $\mathrm{Wi}$ & e V-s & hape & & & & & Narr & $\mathrm{WW}$ U & hape & \\
\hline Top & & & traig & & & & & & & Angle & & \\
\hline Tunnels & & & & & & & & & & & & \\
\hline Type & & Close & top & circu & & Close & lome & & Close & top & rcula & \\
\hline Guiding structure & & T-sha & e wi & th ro & & & & & & None & & \\
\hline Number & & & 5 & & & & & & & 5 & & \\
\hline Diameter $(\mathrm{cm})$ & 40 & 50 & 40 & 40 & 40 & & th) & & & $30(\mathrm{al}$ & & \\
\hline Length (m) & 11 & $?$ & 11 & 16 & 12 & 25 & 19 & & & $10(\mathrm{al}$ & & \\
\hline Material d & $\mathrm{M}$ & $\mathrm{Cc}$ & $\mathrm{M}$ & $\mathrm{M}$ & $\mathrm{M}$ & Pc & Pc & $\mathrm{P}$ & $\mathrm{P}$ & $\mathrm{P}$ & $\mathrm{M}$ & $\mathrm{P}$ \\
\hline Water ${ }^{\mathrm{e}}$ & $\mathrm{R}$ & $\mathrm{R}$ & $\mathrm{D}$ & $\mathrm{R}$ & $\mathrm{R}$ & $\mathrm{S}$ & $\mathrm{R}$ & $\mathrm{D}$ & $\mathrm{S}$ & $\mathrm{S}$ & $\mathrm{D}$ & $\mathrm{R}$ \\
\hline Max water depth $(\mathrm{cm})$ & 10 & 5 & - & 5 & 5 & 5 & 1 & - & 30 & 25 & - & 5 \\
\hline Distance between (m) & 55 & 5 & & 70 & 75 & & & 47 & 5 & & $5^{f}$ & 115 \\
\hline
\end{tabular}

4 a: Data from 2007-2015

5 b: Including pedestrian and bike lanes

6 c: Not clear whether these were in place during monitoring

$7 d: M=$ metal, $C c=$ cement concrete, $P c=$ polymer concrete, $P=$ plastic

8 e: $R=$ running, $D=d r y, S=$ standing (at the time for fieldwork)

$9 f$ : Including distance between mitigated sections 


\section{Table 2 (on next page)}

Amphibian data collection methods and efforts at the three study sites near Stockholm, Sweden. 
1 Table 2. Amphibian data collection methods and efforts at the three study sites near Stockholm, 2 Sweden.

\begin{tabular}{|c|c|c|c|c|c|c|}
\hline \multirow[t]{2}{*}{ Site } & \multicolumn{2}{|c|}{ 1. Skårby } & \multicolumn{2}{|c|}{ 2. Kyrksjölöten } & \multicolumn{2}{|c|}{ 3. Skeppdalsström } \\
\hline & Before & After & Before & After & Before & After \\
\hline \multicolumn{7}{|l|}{ Visual search } \\
\hline Section searched $(\mathrm{m})$ & \multicolumn{2}{|c|}{520} & \multicolumn{2}{|c|}{ ca 1000} & \multicolumn{2}{|c|}{ ca 950} \\
\hline No. of nights & 1 & 4 & $17^{\mathrm{a}}$ & $3^{b}$ & 7 & 4 \\
\hline Time period & $\begin{array}{c}15-16 \text { April } \\
2004\end{array}$ & $\begin{array}{c}\text { 6-22 April } \\
2008\end{array}$ & $\begin{array}{c}27 \text { March } \\
-9 \text { May } \\
2012\end{array}$ & $\begin{array}{c}\text { 8-15 April } \\
2015\end{array}$ & $\begin{array}{c}\text { 7-19 April } \\
2015\end{array}$ & $\begin{array}{c}\text { 7-18 April } \\
2016\end{array}$ \\
\hline \multicolumn{7}{|c|}{ Pitfall trapping along temporary fences } \\
\hline Section trapped (m) & \multicolumn{2}{|c|}{-} & 350 & - & \multicolumn{2}{|c|}{-} \\
\hline No. of nights & \multicolumn{2}{|c|}{-} & $17^{a}$ & - & \multicolumn{2}{|c|}{-} \\
\hline Time period & \multicolumn{2}{|c|}{-} & $\begin{array}{c}27 \\
\text { March-9 } \\
\text { May } \\
2012 \\
\end{array}$ & - & \multicolumn{2}{|c|}{-} \\
\hline \multicolumn{7}{|l|}{ Net trapping } \\
\hline No. of tunnels & - & 4 & \multicolumn{2}{|c|}{-} & \multicolumn{2}{|c|}{-} \\
\hline No. of nights & - & 5 & \multicolumn{2}{|c|}{-} & \multicolumn{2}{|c|}{-} \\
\hline Time period & - & $\begin{array}{c}\text { 9-11 April } \\
2010,15- \\
18 \text { April } \\
2013\end{array}$ & \multicolumn{2}{|c|}{-} & \multicolumn{2}{|c|}{-} \\
\hline \multicolumn{7}{|l|}{ Camera trapping } \\
\hline No. of tunnels & \multicolumn{2}{|c|}{-} & - & 2 & - & 4 \\
\hline No. of nights & \multicolumn{2}{|c|}{-} & - & $32^{c}$ & - & $7-11^{d}$ \\
\hline Time period & \multicolumn{2}{|c|}{-} & - & $\begin{array}{c}1 \text { April-3 } \\
\text { May } 2015\end{array}$ & - & $\begin{array}{c}\text { 5-23 April } \\
2016\end{array}$ \\
\hline
\end{tabular}

3

a: Representing 7 significant migration nights.

b: Representing a period of 8 days and nights.

c: Representing 14 significant migration nights.

d: Differed between tunnels; see table 4. 


\section{Table 3(on next page)}

Estimated number of amphibians killed per night along the studied road sections before and after mitigation, separated between mitigated and adjacent non-mitigated sections.

Data were standardised to allow comparisons within and among sites; see text for further explanation. 
1 Table 3. Estimated number of amphibians killed per night along the studied road sections before 2 and after mitigation, separated between mitigated and adjacent non-mitigated sections. Data 3 were standardised to allow comparisons within and among sites; see text for further explanation.

4

\begin{tabular}{|l|c|c|c|}
\hline Site 1. Skårby \\
\hline Section & Before & After & $\Delta$ \\
\hline Mitigated & 228 & 10 & -218 \\
\hline Non-mitigated & 91 & 60 & -31 \\
\hline Total & 319 & 70 & -249 \\
\hline Site 2. Kyrksjölöten \\
\hline Section & Before & After & $\Delta$ \\
\hline Mitigated & 32.2 & 7.1 & -25.1 \\
\hline Non-mitigated & 9.9 & 43.1 & +33.3 \\
\hline Total & 42.1 & 48.1 & +8.2 \\
\hline Site 3. Skeppdalsström \\
\hline Section & Before & After & $\Delta$ \\
\hline Mitigated & 25.3 & 0 & -25.3 \\
\hline Non-mitigated & 8.4 & 9.0 & -0.6 \\
\hline Total & 33.6 & 9.0 & -25.9 \\
\hline
\end{tabular}

5

6 


\section{Table 4 (on next page)}

Number of amphibian recordings in the tunnels, and the net number passing through per night or 24h-period.

For site 2-3 (cameras) data are separated between animals moving into the tunnel (i.e. in direction toward the breeding wetland) and those moving out (direction from the wetland). At site 1 (traps), only animals moving toward the wetland could be counted, as net traps blocked the tunnels in the other direction. Tunnels that were not monitored are indicated by lack of data. 
1 Table 4. Number of amphibian recordings in the tunnels, and the net number passing through 2 per night or 24h-period. For site 2-3 (cameras) data are separated between animals moving into 3 the tunnel (i.e. in direction toward the breeding wetland) and those moving out (direction from 4 the wetland). At site 1 (traps), only animals moving toward the wetland could be counted, as net 5 traps blocked the tunnels in the other direction. Tunnels that were not monitored are indicated 6 by lack of data.

7

Site 1. Skårby (only newts, 5 nights during peak migration period)

\begin{tabular}{|l|c|c|c|l|c|}
\hline Tunnel no. & S newt & GC newt & Both sp. & & Net no./night \\
\hline 1 & 473 & 145 & 618 & & 123.6 \\
\hline 2 & - & - & - & & - \\
\hline 3 & 21 & 28 & 49 & & 9.8 \\
\hline 4 & 612 & 90 & 702 & & 140.4 \\
\hline 5 & 111 & 5 & 116 & & 23.2 \\
\hline Sum & 1217 & 268 & 1485 & & 297.0 \\
\hline
\end{tabular}

Site 2. Kyrksjölöten (only common toad, 14 significant migration days)

\begin{tabular}{|l|c|c|c|c|c|}
\hline Tunnel no. & In & Out & Net no. & In+out/24h & Net no./24h \\
\hline 1 & 871 & 397 & 474 & 90.6 & 33.9 \\
\hline 2 & 545 & 216 & 329 & 54.4 & 23.5 \\
\hline Sum & 1416 & 613 & 803 & 144.9 & 57.4 \\
\hline
\end{tabular}

Site 3. Skeppdalsström (all amphibians, 7-11 days during peak migration period)

\begin{tabular}{|l|c|c|c|c|c|}
\hline Tunnel no. & In & Out & Net no. & In+out/24h & Net no./24h \\
\hline 1 (9 days) & 41 & 17 & 24 & 6.4 & 2.7 \\
\hline 2 (11 days) & 258 & 254 & 4 & 46.5 & 0.4 \\
\hline 3 (7 days) & 70 & 38 & 32 & 15.4 & 4.6 \\
\hline 4 (7 days) & 20 & 0 & 20 & 2.9 & 2.9 \\
\hline 5 & - & - & - & - & - \\
\hline Sum & 389 & 309 & 80 & 71.2 & 10.5 \\
\hline
\end{tabular}

8 


\section{Table 5 (on next page)}

Estimated number of amphibians successfully crossing the road per night along the studied road sections before and after mitigation, separated between mitigated and adjacent non-mitigated sections.

Data were standardised to allow comparisons within and among sites; see text for further explanation. 
Table 5. Estimated number of amphibians successfully crossing the road per night along the studied road sections before and after mitigation, separated between mitigated and adjacent non-mitigated sections. Data were standardised to allow comparisons within and among sites; see text for further explanation.

5

6

\begin{tabular}{|l|c|c|c|}
\hline Site 1. Skårby \\
\hline Section & Before & After & $\Delta$ \\
\hline Mitigated & 139.1 & $303.1^{\text {a }}$ & +164.0 \\
\hline Non-mitigated & 55.5 & 36.6 & -18.9 \\
\hline Total & 194.6 & 339.7 & +145.1 \\
\hline Site 2. Kyrksjölöten \\
\hline Section & Before & After & $\Delta$ \\
\hline Mitigated & 13.8 & $60.5^{\mathrm{a}}$ & +46.6 \\
\hline Non-mitigated & 4.3 & 18.5 & +14.3 \\
\hline Total & 18.1 & 79.0 & +60.9 \\
\hline Site 3. Skeppdalsström & & \\
\hline Section & Before & After & $\Delta$ \\
\hline Mitigated & 8.4 & $10.5^{\mathrm{a}}$ & +2.1 \\
\hline Non-mitigated & 2.8 & 3.0 & +0.2 \\
\hline Total & 11.2 & 13.5 & +2.3 \\
\hline
\end{tabular}

7

a: Including the number passing through tunnels; see table 4.

8 